\title{
TRENDS IN URBAN FORESTRY PRACTICES, PROGRAMS, AND SUSTAINABILITY: CONTRASTING A PENNSYLVANIA, U.S., STUDY
}

\author{
by William F. Elmendorf', Vincent J. Cotrone ${ }^{2}$, and Joseph T. Mullen ${ }^{3}$
}

\begin{abstract}
Previous studies provided criteria and guidelines both for measuring and increasing the sustainability of urban forests. These studies have also provided evidence that difficulties existed in completing important practices (e.g., inventories, street tree ordinances, management plans), which contribute to both better urban forest programs and sustainability. In a recent study of both small town tree commissions and programs in northeastern Pennsylvania U.S., there was a marked difference between tree commission members' attitudes toward urban forestry practices and the successful completion of them. Focus groups composed of tree commission members were used to gather information on why these differences existed. Our northeastern Pennsylvania study provided evidence that local tree commissions had difficulties completing urban forestry practices for a number of reasons, including a lack of volunteer time and a need for additional support and assistance. The study also showed that small town tree commissioners viewed and defined urban forest sustainability much more practically than has been expressed in the extant literature. Questions continue about how well local urban forestry practices support sustainable urban forest programs and resources.
\end{abstract}

Key Words. Urban forestry practices; urban forestry sustainability; urban forestry programs; tree commission; planning commission; tree management; land use.

Urban forestry has expanded tremendously since the first National Urban Forestry Conference in 1978 (Zipperer et al. 1991). Traditionally, urban forestry was focused on managing and maintaining street and park trees, and a spirit of community support and volunteerism continues to be important (Groninger et al. 2002). Today, urban forestry also considers land use decisions related to natural resources and the preservation and management of trees and greenspace affected by development on private property (Sievert 1994; Elmendorf and Luloff 1999; Dwyer et al. 2000) Thus, for some, the definition of the urban forest has grown to include not only the public landscape of streets and parks but also the private landscape of trees and other natural resources involved in planning and decision making related to community growth and development. In fact, some authors are of the opinion that one of the most powerful forces directly affecting urban forestry structure and sustainability today is land use policy and land use change (Dywer et al. 2000; Nowak et al. 2001). To accept that urban forestry has expanded, one must accept the idea that trees and other natural resources on private property, and public policy affecting them, are important components of the urban forest.

For the past 100 years, cities, boroughs, incorporated towns, and townships have been empowered by state administrative codes to establish shade tree commissions. These volunteer commissions typically concentrate on the management and maintenance of public street and park trees. They can include appointed volunteers, elected officials, or others. In general, municipalities enacting these commissions may appoint members to the body and may empower the body as decision making or as advisory to the elected municipal legislature. Commissions may be empowered to place or not place on landowners the responsibility for tree planting, pruning, and removal; to tax the community to pay for tree care; to complete tree inventories; and to enact street tree and other ordinances. They should be authorized to develop management and maintenance plans, develop annual work plans and budgets, and promote community education and participation. They should also be provided the authority to establish permit, public hearing, and enforcement processes for public tree protection, removal, pruning, and planting (Elmendorf and Gerhold 2000).

In a dynamic mix, there are alternatives and additions to municipal tree commissions to plan for and manage the urban forest. Municipalities use park, forestry, and public works departments, park commissions, and code enforcement offices to manage public trees. Today, with the shifting character of both suburban and rural development and population, municipal and county planning departments are becoming increasingly involved in setting and enforcing tree preservation ordinances and other policies for managing trees and other natural resources both on public and private property. Some states, such as Maryland, have taken an active role in setting and enforcing policy and managing trees and other natural resources on both public and private property, and in providing policy and funding for the 
conservation of natural resources during development (Galvin et al. 2000). Adding to the dynamics, land conservancies and other nonprofit organizations are becoming increasingly involved in conserving and managing important urban forest resources.

Because of concern for the quality of the environment and life in human settlements, and the changing state of the urban forest in many developing areas, questions regarding how the practices of local urban forestry programs influence urban forest sustainability continue to arise. This paper will provide a review of past studies of local urban forestry practices, programs, and sustainability in the United States. It will also discuss and contrast small town urban forestry programs in northeastern Pennsylvania, the attitudes of involved tree commission members, important practices, how people involved in these programs define sustainable urban forestry programs, and whether their practices are sufficient to support sustainable programs and forests at some level.

\section{WHAT ARE SUSTAINABLE URBAN FORESTS?}

Many authors believe that both the term and goal of sustainability are vague, and many have defined and discussed meanings of the term and strategies to achieve it (Floyd et al. 2001). Aldo Leopold discussed resource conservation in terms that may be recognized today as being reflective of sustainable resource management (Zeide 1998). Leopold used the following terms (Callicott 1993): "a universal symbiosis with the land, economic and aesthetic, public and private;" "as an effort to preserve both beauty and utility;" and "as a positive exercise of skill and insight, not merely a negative exercise of abstinence and caution." Further, Leopold $(1933,1949)$ wrote, "A thing is right when it tends to preserve the integrity, stability, and beauty of the biotic community. It is wrong when it tends otherwise." Today, many agree that "social" could be added to biotic in this thesis.

According to Nowak (1993), there are a number of human and natural forces that influence the long-term structure, use, management, and sustainability of urban forests. Direct human forces include peoples' planting preferences on public and private property, maintenance, funding, land use, and land use change. The construction and management of flood control, streets, parking lots, utilities, and other gray infrastructure are also important direct human forces. Indirect human forces include increased support and interest, partnerships, citizen concern, population change, urban/rural migration, and technology for measuring and monitoring. Direct natural forces include weather, fire, plant aging, and insects and diseases, while indirect include natural forces and disasters that have indirect environmental impacts and/or affect population movements, such as volcanic eruption.
Clark et al. (1997) and Clark and Matheny (1998) discussed urban forest sustainability and the application of a sustainability model to cities in the United States. They defined a sustainable urban forest as "the naturally occurring and planted trees in cities which are managed to provide the inhabitants with a continuing level of economic, social, environmental, and ecological benefits today and into the future." To apply this definition of sustainability to a place, acknowledgement of three ideas was important (Clark et al. 1997): city trees provide a wide range of benefits; resource regeneration requires intervention and management by humans; and sustainable urban forests exist within defined geographic and political borders and are composed of both publicly and privately owned vegetation.

The sustainability model developed by Clark et al. (1997) consisted of three broad categories or components: vegetative resources (e.g., knowledge of the vegetative resource). community framework (e.g., interaction and cooperation of constituent groups), and resource management (e.g., current resource management programs). Within these broad categories, the authors developed key performance indicators or criteria to measure sustainability such as age and species distribution for vegetative resources; neighborhood action and organizational interaction for community framework; and citywide management, funding, and assessment for resource management (Clark and Matheny 1998).

In an assessment of the nation's urban forests, Dwyer et al. (2000) provided six elements important in moving toward urban forest sustainability: improved inventory and monitoring of urban forest resources; improved dialog among owners, managers, and users; collaboration among agencies and groups; improved understanding of urban forest configurations and their impacts on benefits; increased knowledge about urban forestry health; and improving dissemination of information over a wide variety of topics.

\section{A REVIEW OF MUNICIPAL URBAN FORESTRY STUDIES}

Although past research on municipal urban forestry practices has been limited and did not share a common methodology, an important overview can be gained from the results of a number of past surveys. It should be noted that the studies cited in this review had different research methods, looked at different population and land sizes, surveyed different types of people and organizations, and asked different types of questions. The objective of this review is to provide an overview of what people and municipalities have practiced in urban forestry (Table 1).

The results of a nationwide survey of cities published by Kielbaso et al. (1988) reported that 39\% of respondents had systematic tree care programs, $52 \%$ had some form of tree 
Table 1. Comparison of some urban forestry practices.

\begin{tabular}{|c|c|c|c|c|c|c|c|c|}
\hline \multirow[b]{2}{*}{$\underline{\text { Year }}$} & \multirow[b]{2}{*}{ Author } & \multirow[b]{2}{*}{ Area (sample size) } & \multicolumn{6}{|c|}{ Percentage of respondents completing various urban forest practices } \\
\hline & & & Inventory & $\begin{array}{l}\text { Tree } \\
\text { ordinance }\end{array}$ & $\begin{array}{l}\text { Preservation } \\
\text { ordinance }\end{array}$ & Tree plan & $\begin{array}{l}\text { Systematic } \\
\text { pruning/care }\end{array}$ & Arbor Day \\
\hline 1990 & Kielbaso & Nationwide $(1,059)$ & - & 61 & 13 & 16 & - & 49 \\
\hline 1993 & Reeder & Muni./PA (322) & 78 & 23 & - & - & 20 & - \\
\hline 1994 & Ricard & Muni./CT (168) & 19 & 11 & - & - & - & - \\
\hline 1995 & Allen & Small town/MO (140) & - & 8 & 4 & 2 & - & 23 \\
\hline 1998 & Clark & Nationwide (25) & 36 & - & - & 64 & - & - \\
\hline 2001 & Elmendorf et al. & Small town/PA (188) & 43 & 78 & 13 & 29 & 48 & 50 \\
\hline
\end{tabular}

inventory (of which 32\% were computerized), and 68\% had municipal tree ordinances. Respondents reporting ordinances indicated that $70 \%$ regulated species selection for planting, 68\% defined maintenance responsibilities, 78\% regulated removals, and 28\% required replacement of trees that were removed. In a further analysis of trends and issues in city forests, Kielbaso (1990) reported that 16\% of the cities had urban forest management plans and 27\% had plans to manage disaster situations related to the urban forest. Further, $61 \%$ of cities had street tree ordinances and $13 \%$ had ordinances that dealt with restricting the unnecessary removal of trees on private property, usually during development. Forty-nine percent of cities celebrated Arbor Day and 26\% of cities participated in the National Arbor Day Tree City program.

In a Pennsylvania study of municipalities, which indicated they had an active urban tree program, Reeder and Gerhold (1993) reported higher percentages of tree care programs in cities than in boroughs or townships. The authors used incorporation rather than size to distinguish between these municipalities. In general, cities are large, boroughs are smaller, and townships are both small and rural. Eighty-one percent of cities, $25 \%$ of boroughs, and $6 \%$ of mostly rural townships had tree programs. Nearly half of the respondents who indicated they had tree programs had no shade tree commission. Of the respondents indicating a shade tree commission, $87 \%$ met once a year and $67 \%$ met twice or more a year. Seventy-eight percent of the municipalities had some form of tree inventory, and 23\% had some form of a tree ordinance. Seventy-two percent of municipalities had a list of desired tree species for planting. Forty-four percent planted trees annually, while 36\% planted trees less than once a year, and 24\% either never or only when trees were removed. Fifty-seven percent of the respondents indicated that the authority to plant trees rested with the municipality.

Reeder and Gerhold (1993) also reported that no more than $20 \%$ of the municipalities reported regular pruning, and $47 \%$ reported that pruning was done by municipal employees. Trees were removed through a variety of options, with removal by municipalities (79\%) and landowners (53\%) the largest numbers. Respondents showed a deep interest in education and technical assistance. Eighty-one percent indicated that information over a wide variety of topics (e.g., highest interest was cost-sharing programs; lowest interest was bird watching) would be helpful.

In a survey of tree activists, chamber of commerce members, municipal officials, and elected officials in 168 Connecticut municipalities, Ricard (1994) found that 11\% had shade or street tree ordinances. Thirty-seven percent thought that municipalities should adopt an ordinance, while $40 \%$ thought they should not. Identically, $11 \%$ of responding municipalities had shade tree commissions. Thirty-seven percent of respondents felt that municipalities should have a tree commission; $40 \%$ thought they should not. Nineteen percent of the municipalities had an inventory, of which $14 \%$ were computerized. When asked about city or town foresters, $26 \%$ of municipalities reported that they had foresters, but only three town foresters were confirmed in the state. This discrepancy may have occurred if tree wardens were recognized as town or city foresters. Sixtyfour percent of the respondents thought that municipalities should have a forester, and $41 \%$ of the respondents reported that their municipality budgeted specifically for tree maintenance and protection. Ricard (1994) also reported that there was strong agreement among all groups (tree activists, chamber of commerce, and municipal officials) about urban and community forestry importance, the importance of an array of benefits, and the necessity of wise management. Respondents welcomed technical assistance, educational programs and publications, and desired more help from state government.

A 1998 survey of Illinois municipalities with a population less than 25,000 (Green et al. 1998) gathered information on small-town tree programs from chief elected officials. In their study, the authors found that municipal officials had very strong positive attitudes toward the values of community trees. They also found significant differences between the 
practices of the smaller and larger municipalities within the study population parameters. Smaller municipalities were less likely to have tree commissions, tree ordinances, or a person assigned responsibility for tree care. Eighty-five percent of the respondents agreed municipalities should provide funding for tree removal and close to $72 \%$ for tree planting.

Thirty-three percent had street tree ordinances, with $8 \%$ of these ordinances considered adequate when requirements for tree planting lists, site analysis, and removal of dangerous or diseased tree on private property were reviewed. Eightypercent of the respondents didn't know the number of public trees, 15\% had tree inventories, with $7 \%$ of these being updated. Fifty-seven percent assigned responsibility for public trees and, of these, $8 \%$ were to foresters or arborists, while $64 \%$ were to people with no training in tree care. Eighty-two percent of responding municipalities provided tree removal, $82 \%$ provided pruning on request, $62 \%$ provided recycling of wood waste, $60 \%$ provided cyclical pruning, and $41 \%$ provided community education. Forty-six percent of the respondents were aware of grants, with 19\% having applied. Fifty-three percent had some celebration for the value of trees and 32\% percent celebrated Arbor Day. Seventy-two percent agreed that the state should provide personnel and technical assistance, and 66\% wanted further assistance to develop their tree program.

In a survey of municipal employees in 236 municipalities in Missouri, Allen (1995) gathered information about attitudes of municipal employees toward urban forestry programs and tree program behavior. Overall, $4 \%$ of responding municipalities had management plans, 13\% had tree ordinances, $8 \%$ had ordinances to protect trees on private property, $12 \%$ used integrated pest management, and 28\% celebrated Arbor Day. When looking at metropolitan areas, $6 \%$ had management plans, $21 \%$ had tree ordinances, $13 \%$ had ordinances to protect trees on private property, and $37 \%$ celebrated Arbor Day. For rural places, $2 \%$ had management plans, $8 \%$ had tree ordinances, $4 \%$ had ordinances that protected trees on private property, and 23\% celebrated Arbor Day.

Allen (1995) also reported that regardless of region, population class, metropolitan or rural community, or Tree City USA status, respondents had a positive attitude toward the benefits of the urban forest, had positive attitudes toward urban forestry, and alternatively believed that urban trees could be dangerous and cause problems to infrastructure, such as sidewalks and utilities. However, respondents from metropolitan communities were significantly more supportive of increased funding and taxes for urban tree management than those from rural communities.

In their survey work on urban forest sustainability, Clark and Matheny (1998) described a problem with the qualitative measurement of urban forest sustainability and responded by devising a methodology for a survey of staff members in 25 larger cities (30,000 to 750,000 in population) in the United States. The authors found a diversity of attitudes toward urban forests, both positive and negative, in large city departments. In general, public utility, school district, and public works departments had less positive attitudes, while parks, forestry, and planning had more positive. Thirty-six percent of the cities had complete inventories of public trees, $40 \%$ incorporated resource management information in GIS systems, and 64\% had management plans dealing with public trees. Only one city had a management plan that considered both public and private trees.

Clark and Matheny (1998) reported that when considering the indicators or criteria of their sustainability model, the average sustainability score for vegetative resources was 8 with a maximum of 16 , or $50 \%$. The average score for community framework was 18 with a maximum of 28 , or 64\%; and the average score for resource management was 22 with a maximum of 36 , or $61 \%$. Other findings included wide variations among cities when measuring urban forest sustainability; that sustainable urban forests required human interaction; and that trees on private land comprised the majority of the urban forest. Further, they concluded that integrating the management of private lands into a citywide plan was a significant challenge; a shared vision of treatment of resources on private property was required; and regional cooperation and the interaction of neighboring communities was important in urban forest management.

\section{METHODS}

Our investigation in northeastern Pennsylvania was funded by the USDA Forest Service and broken into three components: Component 1 measured the attitudes of shade tree commissioners about urban forests and urban forestry practices; Component 2 gathered factual data about the practices of municipalities involved in Stage 1; and Component 3 used focus groups of involved tree commission members to help interpret the results of the mail surveys.

\section{Component 1}

This self-administered survey (Survey of Tree Commissions) consisted of 54 statements covering the criteria developed for the urban forest sustainability model developed by Clark et al. (1997). Questions, most using 5-point Lykert-type scales, were broken into sections on tree values and benefits, tree planting, managing the urban forest, tree maintenance, tree preservation, tree commissions, and tree program funding. Open-ended questions asking about the relationship between a vision for community development and trees, practices of a sustainable tree program, and obstacles to achieving sustainable tree programs were also included. Limited amounts of socio/demographic data about the respondents were collected in this survey including age, sex, length of residence, position, and length in position. 
Survey instrument administration was based on a modified Dillman Total Design Method, which has been described at length in other publications (Dillman 2000). In October 2000, the survey was mailed to 265 shade tree commission members, with 188 surveys being completed and returned, a response rate of $71 \%$.

\section{Component 2}

This self-administered survey (Survey of Municipal Tree Programs) consisted of 93 questions asking for factual data about the practices (e.g., tree inventories, street tree ordinances, management plans, fund raising) important to a successful municipal tree program. Questions, most based on a yes or no response, were developed using the criteria developed by Clark and Matheny (1998). Questions were broken into sections on tree inventory and inspection, tree planting, tree health and maintenance, your municipal forest, street tree ordinances, tree commissions, volunteers, community relations, education, and tree program funding. No socio/demographic data were collected in this survey. The survey was administered in a manner corresponding to Component 1. In November 2000, the survey was sent to 68 municipal managers whose tree commission members were surveyed in Component 1. Fifty-six percent were completed and returned for a response rate of $82 \%$. Both surveys were compiled using SPSS. For this study, descriptive statistics were run for each data set and frequency tables were then analyzed for trends in attitudes and program practices.

\section{Component 3}

When examining the data gathered from corresponding tree commissioners and programs, it became apparent that there were often substantial differences between the attitudes of tree commission members and the practices actually being implemented in their programs. For this publication, the authors decided to examine these differences and investigate possible explanations for them. To assist in this matter, and to provide input from those involved and affected, two focus groups were held with 12 active members of shade tree commissions in northeastern Pennsylvania. The agenda of the focus sessions was outlined by the authors. Focus groups facilitated their own discussions, and results were recorded by hand by three Extension staff and later evaluated by the authors.

\section{RESULTS OF NORTHEASTERN PENNSYLVANIA MAIL SURVEYS (NPS)}

As an aid to the reader, the results of the Component 1 survey on attitudes and the Component 2 survey on program practices are reported together (Table 2 ). When considering tree inventories, $83 \%$ of the respondents felt they were important, and $43 \%$ of the programs had completed one. Of those municipalities completing inventories,
$67 \%$ used their inventory in management and maintenance. Eighty-eight percent of the respondents thought that annual tree inspections were necessary, and 52\% of the programs were completing annual inspections.

With regard to tree maintenance, 29\% said that tree care was adequate, and $53 \%$ said they did not have adequate personnel for tree care. Eighty-six percent of respondents said that trees should not be topped or incorrectly pruned, while $75 \%$ reported that trees were being topped or incorrectly pruned. Thirty-three percent of respondents felt that utility companies were pruning trees correctly. Ninetyeight percent of respondents said that removing dangerous trees annually was important, and $73 \%$ of municipalities were removing trees on an annual basis.

When considering tree planting, $84 \%$ of respondents said that annual tree planting was important and 56\% reported it was occurring. Eighty-eight percent of respondents said that it was important to evaluate planting sites, and $69 \%$ said that sites were being evaluated.

With regard to street tree ordinances, 93\% of respondents said they were important, and $78 \%$ had a street tree ordinance. Of these, $20 \%$ did not enforce their ordinance, and $63 \%$ said that trees were removed without permission. Only thirty-five percent required adherence to ANSI A300 pruning standards, $22 \%$ to nursery standards, and $21 \%$ to ANSI Z133 safety standards.

When considering trees on private property, $81 \%$ of respondents said that tree preservation ordinances should be used. Thirteen percent had a tree preservation ordinance. Nineteen percent of municipalities reported that they were preserving woodlots in development, and $20 \%$ said they were preserving historic trees.

When considering community tree plans, $90 \%$ of the respondents said they were necessary, and 29\% of the programs had a tree plan. Ninety-three percent of respondents said that it was important to hold public meetings to discuss tree planting and removal, $27 \%$ held meetings for removals, and $40 \%$ held meetings for plantings.

When considering tree commission education and outreach, $94 \%$ of respondents said it was important that tree commissions receive continuing education. Fewer than half of the commissions were receiving continued education or new member training. Fewer than half said they were educating homeowners and municipal officials. Education of public work crews, the media, and members of the green industry was done at even lower levels. When asked about using volunteers for planting and pruning young trees, $91 \%$ of the respondents said it was important, and 63\% were using volunteers. When asked about advertising their programs and building community support $67 \%$ said it was important, and 50\% said they advertise their program. Forty-three percent prepared an annual report, 11\% had a brochure or newsletter, and 50\% celebrated Arbor Day. 
Table 2. Pennsylvania mail survey attitudes and practices responses.

\begin{tabular}{|c|c|c|}
\hline Component & Attitude (\%) & Practice (\%) \\
\hline Tree inventory & 83 necessary & $\begin{array}{l}43 \text { completed } \\
67 \text { use inventory }\end{array}$ \\
\hline Annual inspections & 88 necessary & 52 do \\
\hline Adequate tree care & 100 important & $\begin{array}{l}29 \text { have } \\
51 \text { pruned every } 10 \text { years }\end{array}$ \\
\hline Topping other poor practice & 86 should not & 75 trees are \\
\hline Utilities prune properly & 33 yes & 43 meet with utilities \\
\hline Hazard trees removed annually & 98 important & 73 complete \\
\hline Use ISA Certified Arborists & 71 important & 25 use \\
\hline Trees planted annually & 84 important & 56 complete \\
\hline Sites evaluated & 88 important & 69 complete \\
\hline Street tree ordinance & 93 important & $\begin{array}{l}78 \text { have } \\
20 \text { do not enforce } \\
63 \text { trees removed no permission }\end{array}$ \\
\hline Ordinances require standards & 85 important & $\begin{array}{l}35 \text { ANSI pruning } \\
21 \text { ANSI safety } \\
22 \text { nursery standards }\end{array}$ \\
\hline Tree preservation ordinances & 81 important & $\begin{array}{l}13 \text { have } \\
19 \text { have landscape ordinance }\end{array}$ \\
\hline Zoning used to preserve trees & 59 should & 19 are \\
\hline Preserving trees in development & 87 important & 20 preserving historic trees \\
\hline Tree plan & 90 necessary & 29 completed \\
\hline Tree commission has education & 94 important & $\begin{array}{l}45 \text { complete } \\
47 \text { new members trained }\end{array}$ \\
\hline Tree commission educates & 92 important & $\begin{array}{l}92 \text { officials } \\
39 \text { homeowners } \\
28 \text { public works } \\
19 \text { media }\end{array}$ \\
\hline Use volunteers & 91 important & 63 use \\
\hline Advertising program/build support & 67 important & $\begin{array}{l}50 \text { advertise } \\
43 \text { annual report } \\
60 \text { celebrate events } \\
50 \text { celebrate Arbor Day } \\
11 \text { brochure/newsletter }\end{array}$ \\
\hline Funding should be municipal only & 19 agree & $\begin{array}{l}89 \text { municipal funding } \\
21 \text { agree effective with municipal } \\
39 \text { adequate funding } \\
23 \text { fundraise } \\
84 \text { use grants } \\
40 \text { grants largest source } \\
61 \text { program needs grants }\end{array}$ \\
\hline
\end{tabular}

With regard to funding, 19\% of respondents agreed that tree programs should be funded solely through local tax dollars, while $89 \%$ received all their funding from their municipality's general fund. Only $23 \%$ used fund raising. Twenty-one percent of respondents agreed that their tree program received enough funding from the municipality to function effectively.

\section{RESULTS OF NORTHEASTERN PENNSYLVANIA FOCUS GROUPS}

To better understand the barriers between tree commission members' attitudes and the implementation of program practices, and to gather input on sustainable urban forestry, two focus groups were asked to consider a series of questions on urban forestry practices and sustainability.

When asked to consider the barriers between attitudes and practices found in Table 2, focus group members made statements about support and understanding, assistance, organization, and energy and time (Figures 1 and 2). Although many ideas and thoughts were provided in the focus group work, at least nine nonmutually exclusive themes were echoed within the recorded focus group: (1) a lack of time and energy of volunteer commissions to complete tasks; (2) a need for more support from citizens and leaders; (3) leaders and residents did not understand, or had a negative understanding, of tree values and benefits; (4) a lack of assistance by municipal staff, volunteers, and qualified arborists; (5) weak or poor organization; (6) concern for private property rights and too much government; (7) a need for more knowledge; (8) small-town politics; and (9) not enough funding. During the focus group sessions, funding was the last theme to be identified and discussed by the group members. 
When asked to define sustainability (Figure 3), among other things, focus group participants talked about maintenance, planting, support, and understanding, and an element of program over time. They also had opinions about what was needed for a sustainable urban forestry program (Figure 4). Here participants discussed an established energized commission; support of citizens, leaders, volunteers, and the state; education of commission members; adequate funding; and mission, ordinances, and awards.

- Committed and dedicated tree commission (energy and time).

- Outreach and education, community awareness of tree benefits and values (understanding).

- A community tree plan including a mission or vision statement (organization).

- Professional and staff involvement with and assistance to commission (assistance).

- Community involvement, support, and commitment (support).

- Support of leaders, financial support, and enforcement of ordinances (support).

Figure 1. What is needed for completion of urban forestry practices?

- Gaining leader and council support. Turnover of leaders, communications must be done consistently, commission members change, and leaders only have so much time for competing issues (understanding and support).

- Gaining commitment and cooperation of citizens because of many faces, many people, personalities, and interests (understanding and support).

Figure 2. Largest difficulties in completing urban forestry practices.

\section{DISCUSSION}

\section{Contrasting Studies of Urban Forestry Practices}

Although contrasting studies of practices of urban forestry (Table 1) is difficult because of different research methods, conducting such a study provides an interesting overview. At generally low to moderate levels, ordinances and were the most frequent practices completed by municipalities over the past 13 years, while management plans were much less frequent, with the acceptance of the Clark and Matheny (1998) study of cities. Although municipalities may have indicated they had policy documents such as inventories, ordinances, and plans, questions were raised about the degree of use and enforcement of these policies. In addition to use and enforcement, Kielbaso et al. (1988) raised questions, and Green et al. (1998) discussed whether ordinances were adequate when sections for tree planting, site analysis, and removal of dangerous or diseased trees were considered. With regards to ordinances that preserve trees and woodlots on private property, small accomplishments were reported overall, especially in rural areas. The northeastern Pennsylvania study (2001) provided evidence that negative attitudes toward zoning, concerns about governments involvement in private property rights, and a lack of a shared plan or vision within and among municipalities were serious impediments to preserving historic and other trees on private property.

Reeder and Gerhold (1993) and Ricard (1994) discussed the low percentage of active shade tree commissions involved in urban forestry programs, and Reeder and Gerhold (1993), Ricard (1994), and Green et al. (1998) found evidence that the number of trained arborists and urban foresters involved in urban forestry programs was limited. Reeder and Gerhold (1993), Ricard (1994), Green et al. (1998) and the northeastern Pennsylvania study (2001) all provided evidence that there was a desire and need for education and technical assistance to support and expand community involvement in existing tree programs.

Ricard (1994), Allen (1995), Green et al. (1998), Clark et al. (1997) and the northeastern Pennsylvania study (2001) all provided good evidence that citizens, staff, and leaders agreed that urban forest benefits and management were important, but Kielbaso et al. (1988), Reeder and Gerhold (1993), and the northeastern Pennsylvania study (2001) showed that there were low levels of tree planting, systematic pruning, and other tree care. Green et al. (1998) and the northeastern Pennsylvania study (2001) both provided evidence that many tree commissions were not providing community education. They were also not involved in advertising or public relations. The low to moderate level of Arbor Day and other celebrations may be another indicator of tree commission difficulties with marketing and public relations/educational efforts. Reeder and Gerhold (1993), Allen (1995), and Green et al. (1998) provided evidence that smaller municipalities had spent and done proportionately less than larger ones on tree management and maintenance. This difference is most likely due to funding differences between the two. Smaller towns typically have less money to support public services such as urban forestry programs.

\section{Elaborating on the Northeastern Pennsylvania Focus Groups}

In northeastern Pennsylvania, results of focus groups demonstrated that tree commission members were knowledgeable about the practices that must be accomplished for a successful tree program. They knew that tree topping was destructive and that inventories, ordinances, management plans, and preserving trees and woodlots during development were constructive. They understood the need for further training for themselves and that providing education to leaders and residents was important. 
This knowledge is an improvement from the past, but difficulties still remain. It is a reality in the small towns of northeastern Pennsylvania that volunteer tree commissions are charged with providing the time, energy, knowledge, and leadership for urban forestry programs. Many tree commissions in the study area did not have the organizational or functional capacity (e.g., the ability to do work) to effectively carry out urban forestry practices. Without change, this deficiency affects program success, and ultimately it will affect the level of sustainability that can be achieved for the region's urban forests. An important question is what is limiting the capacity of these volunteer commissions to implement important practices and ultimately a higher level of sustainability?

Tree and other commission members, such as planning commissions, are volunteers. The reality of volunteers today means limited time when considering work, family, and recreation. One of the largest problems discussed by participants was the fact that volunteers were "doing it all" and were running out of time, energy, expertise, and at times patience. Furthermore, the administrative codes of Pennsylvania limit the number of shade tree commission members to three in many municipal subdivisions. The constraints of volunteer time to understand and complete practices were only multiplied by a lack of technical assistance, knowledge, and funding. In the focus groups, it became apparent that these volunteers desired additional assistance for carrying out practices.

Focus group participants said they did not have adequate assistance or that resources for assistance were limited or hard to find. Opportunities for staff assistance, including attorneys and other municipal staff knowledgeable about natural resources or natural resource policy were limited. Municipal arborists and municipal foresters were extremely limited in the study area. Further, assistance by certified arborists, cooperative extension, and bureau of forestry staff was limited.

Participants in the focus groups said their efforts required more support by residents and leaders, and that support was difficult to secure. Support was characterized by residents and leaders agreeing that having and managing public trees were both highly important. Related to the concept of support, participants also said that residents and leaders did not fully understand the value and benefits of trees, or had negative attitudes towards trees. The lack of understanding of tree benefits does not exist alone. During discussions, it became evident that focus group participants were starting to recognize the connectivity of practices (Figures 1 and 2) in a sustainable program.

Communicating benefits and values through a planned process of public relations and education is connected to citizen and leader support, or at least tolerance, which is tied to funding and the enactment of public policy such as ordinances. One participant described his program as a "six- headed monster" where "all heads must be fed" for success. It is clear that tree commission members involved in northeastern Pennsylvania focus groups believed they did not have the time for public relations or education. In competitive municipal environments, they were not communicating with leaders and citizens about the values and benefits of their programs or public trees. They discussed a lack of expertise and success in marketing their tree programs and indicated limited time on the part of elected officials to consider a growing and competing number of issues.

Organizational skills were described by participants as deficient. Participants also said that they did not know enough about many technical and managerial aspects of urban forestry. It is difficult to plan and do organizational work when you do not have a full understanding of the substance of your responsibilities.

Participants discussed the difficulties and limitations of working toward preserving trees on private property. Conserving natural resources found on private property through both regulatory and nonregulatory means was a challenge in these small towns because of a traditional conservative nature and the lack of interest of elected officials and municipal staff for passing or enforcing policy limiting private property rights. Further, in Pennsylvania, private property rights and other development policies are debated by planning commissions, zoning hearing boards, and elected officials, not tree commissions. It is important that we separate these entities from tree commissions and that they understand both the importance of trees and other natural resources, and the planning, regulatory, and funding techniques that can conserve them in development.

Participants discussed the realities of small-town politics. Elected officials often shied away from conflict and did not enforce street tree and other ordinances, or enforced them on a selective basis. Ordinances that placed the financial burden of public tree removal and maintenance on adjoining property owners, rather than the general public, were seldom enforced. For the most part, this severely limited the amount of removal and maintenance work being completed. Tree removal and planting decisions often became highly political, and the authority of tree commissions was supplanted by elected officials concerned about political strategies. Again, elected officials in northeastern Pennsylvania generally did not want to debate or consider issues of private property rights and their limitation.

These tree programs existed in small municipalities with low to moderate funding for public services, comparable to many small towns in American. An additional conclusion by the focus groups was that there was not enough funding. As Ricard wrote (1994) about funding for urban forestry programs, "If the sole measure of a community's commitment to its environmental and economic quality is related to how much is spent for programs such as urban and commu- 
nity forestry, it can be emphatically stated that the majority of Connecticut communities are failing." Adequate funding is both an ongoing concern and process in competitive municipal arenas. It correlates with the ability of tree commissions to provide both positive information and opportunities for involvement to people during the course of a year. Municipal funding was seen as inadequate, but again little marketing was being completed, and aside from grant applications, focus group participants' work in fundraising was limited because of time constraints, abilities, and the fact that fund raising is not popular with most volunteers (Still and Gerhold 1997).

When considering sustainability, small towns in northeastern Pennsylvania viewed the term in a much more practical fashion than what has been expressed in the literature (Figures 3 and 4). These people viewed some of the most basic practices of urban forestry as those most important for sustainability, and also as those most difficult to achieve.

- "An area, the tree cover is planted and maintained to continue to provide healthy trees for all time."

- "A committed group of citizens dedicated to preservation, maintenance, and expansion of our urban forest."

- "Diversity, planning, planting, maintenance, removal, celebration, and use. A program that continuously educates the members of the community and tree advocates."

- "A well maintained forest with a dedicated working committee and supportive municipal council that promotes the awareness, celebration, use, and benefits of high quality trees for the future through the use of zoning, ordinances, a maintenance program, and financial support."

- "A place, nurtured and cared for now, but planned for the future; a legacy for others to enjoy."

Figure 3. Definitions of sustainability.

- Established tree commission with historical tradition

- Energized and devoted tree commission

- Dedicated, educated governing body with continuity of support

- Support of citizens over time

- Professional help

- Education of commission and available educational resources

- Management plan and mission

- Available grant funds

- Dedicated, educated volunteers

- Supportive state and federal programs

- Consistent funding

- Ordinances

- Awards

Figure 4. What is needed for a sustainable urban forest?

\section{CONCLUSION}

When considering urban forestry sustainability, Clark et al. (1997) wrote that acknowledgment of three ideas was important: city trees provide a wide range of benefits; resource regeneration requires intervention and management by humans; and sustainable urban forests exist within defined geographic and political borders and are composed of both publicly and privately owned vegetation.

Dwyer and Schroeder (1994) wrote that "Effective urban forest management programs rely on the support of urbanites. Support is most likely to develop when urbanites understand how trees and forests contribute to the quality of urban life, as well as what management is needed to enhance that contribution." Since 1978, a considerable amount of research has been completed on the values and benefits of trees and other green infrastructure, and on their proper planning and management. A question can be asked, "How is urban forestry information being disseminated and is it reaching a significant amount of residents and leaders both in northeastern Pennsylvania and other places?" The northeastern Pennsylvania study suggested that the values and benefits of public trees, and their management, were not fully understood by either residents or leaders. Misperceptions, ignorance, and negative attitudes toward public trees and landscapes and their management continued.

In the competitive organizational environment found within a municipality, program support translates into communication-cultivating an understanding of and caring for tree values and benefits and their management. Sievert (1988) discussed the importance of a commitment to public awareness for successful urban forestry. He stated, "The reason behind the success of urban forestry in Ohio is a commitment to public awareness." He also said, "While public awareness techniques may be successful in one town, they may not be so elsewhere." Providing these and other tree commissions with information not only on tree pruning, planting, and ordinances, but also public relations materials on tree values and benefits and developed materials for press releases and media relations, is important. Local educational and marketing efforts would be facilitated by increased public relations and marketing on larger scales supported by state, federal, or nonprofit agencies. A planned process of communications is essential in building a favorable image for urban forestry, whether at local or larger scales. Abilities, service, contributions, and needs mean little if people do not know about them. As Sievert (1988) discussed, "The uniting component of public awareness is media coverage."

The northeastern Pennsylvania study provided evidence that tree commission members recognized that human interaction was required to manage urban forest resources, but members had difficulty implementing practices due to a number of reasons discussed above including a lack of time, 
energy, and knowledge, a desire for additional assistance and support, and more funding. In the study, it also became evident that not only having a tree commission, but also the involvement of people serving on a commission, impact the success of a program through human attributes such as time, energy, dedication, knowledge, charisma, and sales ability. Education and professional assistance to municipal tree commissions and other commissions involved in planning and managing natural resources should be increased. Furthermore, grant funding that increases the organizational capacity and competitive nature of tree commissions is important. Grants should be provided for a wide range of activities in addition to tree plantings. Urban forestry grants should not only fund tree planting, maintenance, and removal, but also fund opportunities for education and organizational assistance; development of inventories, ordinances, and plans; and development and use of educational and public relations materials.

Urban forest resources on private property were seen as important but were given small attention in northeastern Pennsylvania. This finding supports the results of past studies that examined practices that involved private property rights. A reality of a democratic society is that the economy is to a great extent driven by private investment. Great care continues to be taken to ensure that private property rights are not unduly hindered by government, except in restricted circumstances-especially in private property rights states such as Pennsylvania. There is a historic tension over whether, or to what extent, municipal government, through zoning and other regulation, should interfere with private property rights.

In contrast, many planners are of the opinion that fairly debated and reasonable regulation can both protect and increase private property values and decrease the cost of public services. In America, municipal governments continue to have considerable latitude to use zoning to determine "that the community should be beautiful as well as healthy, spacious as well as clean, well-balanced as well as carefully patrolled (Tibbetts 1995). Preserving trees and other natural resources on private property remains a difficult issue for small town officials, and there were few local policies about this issue. In terms of larger natural systems, such as open space, a shared plan or vision about the treatment of urban forest resources on private property did not exist. Regardless, with development and population growth in northeastern Pennsylvania, discussions and decisions regarding conserving trees and other natural resources, limiting private property rights, and cooperation among municipalities will continue to be undertaken by planning commissions, zoning hearing boards, and elected officials, but not tree commissions. We should be aware that in many small municipalities, volunteer planning commissions share many of the same realities as volunteer tree commissions-limited time and energy, limited knowledge of tree and natural resource values and benefits, a need for more support and assistance, frustrating municipal politics, and limited cooperation between municipalities (State of Pennsylvania 1998; McMahon 2000). To include trees and other natural resources existing on private property in urban forestry sustainability, land use planners, planning commissions, and municipal solicitors must be considered and approached.

Findings of the northeastern Pennsylvania study support the work of Clark et al. (1997); there was variation in local practices, programs, and the sustainability of urban forests. Questions continue about how well local practices are supporting both adequate community tree programs and adequate levels of sustainable urban forest resources. There are examples of excellence in both large and small municipalities, but it may be concluded that there is much room for improvement in many municipalities in accomplishing practices important to sustainable urban forests.

\section{LITERATURE CITED}

Allen, L. 1995. A Social, Economic, and Political Analysis of Missouri's Urban Forest. University of Missouri, Columbia, MO. 135 pp.

Callicott, J.B. 1993. A brief history of American conservation philosophy, pp 10-14. In Covington, J., and L. DeBono (Eds.). Sustainable Ecological Systems: Implementing an Ecological Approach to Land Management. USDA Forest Service Rocky Mountain Forest and Range Experiment Station, Fort Collins, CO.

Clark, J.R., and N.P. Matheny. 1998. A model of urban forest sustainability: Application to cities in the United States. J. Arboric. 24(2):112-120.

Clark, J.R., N.P. Matheny, G. Cross, and V. Wake. 1997. A model of urban forest sustainability. J. Arboric. 23(1):17-30.

Dillman, D. 2000. Mail and Telephone Surveys: The Total Design Method. Wiley, New York, NY. 260 pp.

Dwyer, J.F., and H.W. Schroeder. 1994. The human dimensions of urban forestry. J. For. 92(10):12-15.

Dwyer, J.F, D.J. Nowak, M.H. Noble, and S. Sisinni. 2000. Connecting People with Ecosystems in the 21st Century: An Assessment of Our Nation's Urban Forests. USDA Forest Service North Central Research Station, Evanston, IL. 483 pp.

Elmendorf, W.F., and H.D. Gerhold. 2000. Forming a municipal tree commission, pp 5-6. In Elmendorf, W., and H. Gerhold (Eds.). A Guide For Community Tree Commissions. The Pennsylvania Forestry Association, Mechanicsville, PA. 48 pp.

Elmendorf, W.F, and A.E. Luloff. 1999. Using ecosystembased and traditional land-use planning to conserve greenspace. J. Arboric. 25(5):264-273. 
Floyd, D.W., S.L. Vanholf, and H.E. Seyfang. 2001. Forest sustainability: A discussion guide for professional resource managers. J. For. 99(2):8-16.

Galvin, M.F., B. Wilson, and M. Honeczy. 2000. Maryland's forest conservation act: A process for urban greenspace protection during development process. J. Arboric. 26(5):275-279.

Green, T.L., T.J. Howe, and H.W. Schroeder. 1998. Illinois Small Community Tree Programs: Attitudes, Status, and Needs. Western Illinois University, Macomb, IL. 124 pp.

Groninger, J.W., D.D. Close, and C.M. Basman. 2002. Can small rural communities practice urban forestry? J. For. 100(1):19-22.

Kielbaso, J. 1990. Trends and issues in city forests. J. Arboric. 16(3):69-76.

Kielbaso, J., B. Beauchamp, K. Larison, and C. Randall. 1988. Trends in urban forest management. Baseline Data Report 20(1). International City Management Association, Washington, DC.

Leopold, A. 1933. The conservation ethic. J. For. 31(6):634643.

1949. A Sand County Almanac and Sketches Here and There. Oxford University Press, New York, NY. 295 pp.

McMahon, E.T. 2000. Green infrastructure. Plan. Com. J. $37: 4-7$.

Nowak, D.J. 1993. Historical vegetation change in Oakland and its implications for urban forest management. J. Arboric. 19(5):313-319.

Nowak, D.J., M.H. Noble, S.M. Sisinni, and J.F. Dwyer. 2001. People and trees: Assessing the US urban forest resource. J. For. 99(3):37-42.

Reeder, E.C., and H.D. Gerhold. 1993. Municipal tree programs in Pennsylvania. J. Arboric. 19(1):12-19.
Ricard, R.M. 1994. Urban and Community Forestry Survey Results. University of Connecticut Cooperative Extension System, Haddam, CT. 54 pp.

Sievert, R.C. 1988. Public awareness and urban forestry in Ohio. J. Arboric. 14(2):48-51. . 1994. Urban forestry: A municipal perspective. J. For. 92(10):19-22.

State of Pennsylvania. 1998. Report of the 21st Century Environmental Commission. Governor's Office for Local Government, Harrisburg, PA. 127 pp.

Still, D.T., and H.D. Gerhold. 1997. Motivations and task preferences of urban forestry volunteers. J. Arboric. 23(3):116-129.

Tibbetts, J. 1995. Everybody is taking the fifth. J. Am. Plann. Assoc. 61(1):4-10.

Zeide, B. 1998. Another look at Leopold's land ethnic. J. For. 96(1):13-19.

Zipperer, W.C., L.R. Neville, and G.L. Stokes. 1991. Managing urban sprawl at the fringe, pp 30-32. In Rodbel, P. (Ed.). Alliances for Community Trees: Proceedings of the Fifth National Urban Forest Conferences. The American Forestry Association, Washington, DC. 264 pp.

${ }^{1 *}$ Assistant Professor of Community Forestry

${ }^{2}$ Extension Urban Forester

${ }^{3}$ Urban Forestry Project Assistant

Penn State School of Forest Resources

University Park, PA 16802, U.S.

${ }^{*}$ Corresponding author. 
Résumé. Des études passées ont proposé des critères et des lignes directrices pour à la fois mesurer et accroître le soutien envers les forêts urbaines. Ces études ont aussi fourni des preuves que des difficultés existent pour compléter en entier des pratiques importantes (ex.: inventaires, prescriptions pour les arbres de rues, plans de gestion), ce qui contribuerait à la fois à avoir de meilleurs programmes de foresterie urbaine et un meilleur support. Dans une étude récente à la fois en regard des commissions de l'arbre dans des petites communautés et en regard des programmes, et ce dans le Nord-est de la Pennsylvanie, on a noté qu'il y avait des différences marquées entre l'attitude des membres d'une commission de l'arbre envers les pratiques de foresterie urbaine et l'achèvement avec succès de ces pratiques. Des groupes-témoin composés de membres de commissions de l'arbre ont été utilisés pour recueillir de l'information sur le pourquoi il existe ce type de différences. Notre étude du Nord-est de la Pennsylvanie a fourni des preuves à l'effet que les commissions de l'arbre locales ont des difficultés à achever leurs pratiques de foresterie urbaine pour de nombreuses raisons, dont le manque de temps des bénévoles ainsi que le manque de support additionnel et d'assistance. Létude a aussi montré que les commissions de l'arbre des petites villes perçoivent et définissent le soutien à la forêt urbaine plus de manière pratique, et ce contrairement à ce qui est exprimé dans la littérature existante. Les questions sont toujours présentes en ce qui concerne le comment bien les pratiques locales de foresterie urbaine parviennent à supporter des programmes et des ressources soutenues en foresterie urbaine.

Zusammenfassung. Frühere Studien lieferten sowohl Kriterien als auch Richtlinien für die Messung und das Ansteigen der Nachhaltigkeit urbaner Wälder. Diese Studien haben auch den Beweis erbracht, dass Schwierigkeiten bestehen in der Durchführung wichtiger Arbeiten ( Inventuren, Strassenbaumverordnungen, Managementpläne), welche zu besseren Forstprogrammen und nachhaltigkeit beitragen. In einer kürzlichen Studie über eine Kleinstadtbaumkommision und ihre Programme in Nordpennsylvania waren deutliche Differenzen zwischen der Einstellung der Mitglieder der Forstkommision bezüglich der Praxis und der erfolgreichen Bewältigung der anfallenden Aufgaben. Fokusgruppen aus Mitgliedern der Forstkommision wurden genutzt, um Informationen zu sammeln, warum diese Differenzen bestehen. Unsere Studie in Nordwestpennsylvania liefert Beweise, dass lokale Forstkommisionen wegen einer ganzen Reihe von Gründen Schwierigkeiten haben, ihre Aufgaben zu erfüllen, u.a. aus Mangel an Freiwilligen und dem Bedarf an zusätzlicher Unterstützung und Assistenz. Die Studie zeigt auch, dass Kleinstadtforstkommisionen die Nachhaltigkeit ihrer Wälder viel praktischer betrachten und definieren als in der Literatur zum Ausdruck kommt. Die Fragen bleiben bestehen, wie gut lokale Forstpraktiken die Nachhaltigkeit von Forstprogrammen und Resourcen unterstützen können.

Resumen. Estudios anteriores han proporcionado criterios y guías para medir e incrementar la sustentabilidad de los bosques urbanos. Estos estudios también han dado evidencias de las dificultades existentes para llevar a cabo prácticas de importancia (inventarios, ordenanzas de árboles urbanos, planes de manejo), los cuales contribuyen tanto a mejores programas de bosques urbanos como a la sustentabilidad. En un estudio reciente de pequeños comités y programas en el nordeste de Pennsylvania, hubo una marcada diferencia entre la actitud de los miembros del comité hacia las prácticas de dasonomía urbana y la realización exitosa de las mismas. Se escogieron grupos entre los miembros del comité para obtener información acerca de estas diferencias. Nuestro estudio del nordeste de Pennsylvania proporcionó videncias de que los comités locales de árboles tuvieron dificultades para completar las prácticas forestales urbanas por un número de razones incluyendo la falta de tiempo de los voluntarios y la necesidad de asistencia y soporte adicional. El estudio también mostró que los comisionados vieron y definieron la sustentabilidad del bosque urbano mucho más prácticamente que como ha sido expresado en la literatura. Las preguntas continúan acerca de qué tan bien ayudan las prácticas forestales urbanas locales a los programas y recursos de sustentabilidad. 